\title{
Government Incentives and FDI inflow into R\&D - The Case of Visegrad Countries
}

\author{
Magdalena Owczarczuk
}

\begin{tabular}{|c|c|}
\hline \multicolumn{2}{|r|}{ A B S T R ACT } \\
\hline \multicolumn{2}{|r|}{$\begin{array}{l}m \text { of this article is to identify and compare the efforts of the Visegrad } \\
r \text { to attract more foreign capital to the R\&D sector. }\end{array}$} \\
\hline \multicolumn{2}{|c|}{$\begin{array}{l}\text { Research Design \& Methods: The study is based on the Eurostat's and OECD's data } \\
\text { Considerations about government incentives are based on information gathered by } \\
\text { individual foreign investment promotion agencies. The countries included the study } \\
\text { are the following: Czech Republic, Hungary, Slovakia and Poland. }\end{array}$} \\
\hline \multicolumn{2}{|c|}{$\begin{array}{l}\text { Findings: The countries of the Visegrad Group are perfect example of competition in } \\
\text { attracting foreign investors. In these countries a dynamic growth of foreign } \\
\text { participation in the financing of research and development, as well as a growing } \\
\text { number of emerging international research centres has been observed. Among the } \\
\text { many conditions that shape the investment environment and inflow of investment, } \\
\text { the public R\&D support is seen as a major factor. }\end{array}$} \\
\hline \multicolumn{2}{|c|}{$\begin{array}{l}\text { Implications \& Recommendations: Inflows of foreign direct investment in research } \\
\text { and development has increased substantially during the last years. In the recent years } \\
\text { increased competition can be observed among different countries in attempt for } \\
\text { providing attractive conditions for potential foreign investors in research and } \\
\text { development (R\&D) sector. }\end{array}$} \\
\hline \multicolumn{2}{|c|}{$\begin{array}{l}\text { Contribution \& Value Added: The role of governmental policies is important to build } \\
\text { an economic, institutional and business environment to attract foreign investors and } \\
\text { their R\&D activities. The analysis suggests that investment incentives introduced by } \\
\text { Visegrad countries are not sufficient for FDI inflows to the R\&D. }\end{array}$} \\
\hline Article type: & \\
\hline & \\
\hline & \\
\hline
\end{tabular}

\section{Suggested citation:}

Owczarczuk, M., (2013). Government Incentives and FDI into R\&D. The Case of Visegrad Countries. Entrepreneurial Business and Economics Review, 1(2), pp. 73-86. 


\section{INTRODUCTION}

Investments in R\&D sector are the key factor of steady state economy driven by innovations and the growth of added value of products, processes and services. They contribute to the lasting economic growth and create new valuable workplaces (posts). Due to the low innovativeness of the Visegrad Group (V4) countries and low own expenditures on research and the development, foreign direct investment emerged as a necessary source of funding and development of the R\&D sector in these countries. Statistics show that the Visegrad countries are an attractive locations for foreign investment. In addition, it can be noted that the growing number of investments is related to the capital-intensive sectors, including R\&D sector. For example, compared to 2000, the share of foreign branches in the financing of research and development in Poland has increased by nearly 40 percentage points, in the Czech Republic by more than 20 percentage points. The gradual increase in foreign investment values has encouraged Visegrad's governments to take measures to attract FDI in R\&D sector. In many cases, these governments compete to attract foreign investors. Economic similarity of the Visegrad countries against a background of the whole EU allows to compare these economies with each other also in terms of FDI inflows. The FDI inflows to the R\&D sector in these countries is a relatively new phenomenon, which has not received much scholarly attention yet.

The purpose of this article is to analyse the inflow of foreign investments into R\&D sector in the countries of the Visegrad Group. An essential element of investment attractiveness of these countries is the governmental factor, therefore the system of government incentives directed towards R\&D investment were compared in the study. The article addresses the question whether government investment incentives are sufficient to attract foreign investors to the R\&D sector?

This study is structured as follows. First, it explores the existing literature on FDI factors with a special focus on factors determining FDI in R\&D sector. After presenting the research methodology, characteristics of general foreign direct investment inflow into Visegrad Group countries is discussed. The empirical data analysis is devoted of FDI in the research and development sector. The analysis compares the investment incentives employed by governments in relation to the R\&D foreign investors. Last, conclusions are presented.

\section{LITERATURE REVIEW}

Various motivations of FDI are discussed in the literature within this stream of research. The most popular theories of FDI are associated with the OLI paradigm formulated by J. $H$. Dunning (1993). This eclectic theory of FDI groups these motivation factors into three categories. First, ownership-specific advantages that allow firms to compete with each other firms in the markets, regardless of the disadvantages of being foreign. Second, transaction costs associated with trade and licensing that make the internalized transactions through FDI more efficient. Third, location advantages which make the chosen foreign country a more attractive site for FDI than the others. While O- and Itype advantages are firm specific determinants of FDI, location advantages are countryspecific. They depend, on the one hand, on the home country characteristics that allow a firm to develop ownership advantages and become multinational. On the other hand, 
they depend on the host country characteristics that allow foreign firms already possessing ownership advantages to locate economic activities there (Resmini, 2000, p. 668). Given the objective, I will focus on some of L-type advantages.

Before making a decision on foreign investment, investors compare countries according to certain factors. Foreign investors seek a predictable business environment in which they can make rapid decisions. A favourable business environment usually includes a stable economy and a stable political system. It belongs to location important advantages according to Dunning and Lundan (2008). Although scholars believe that FDI inflows usually depend on fiscal stimulus, the retrospective empirical analysis suggests that fiscal incentives increase corporate profits and inward FDI (Morisset \& Pirnia, 2001; Peters \& Fisher, 2004; Miyagiwa \& Ohno, 2008; Havranek \& Iršova, 2010). A properly selected investment measure promotes the injection of FDI and stimulates the growth of a host country's economy. Rosenboim et al. (2008), in contrast to some scientists, believe that the most significant incentives are grants because they have a long-term affect on MNCs decisions to make investments. Saggi (1999) notes that MNCs invest in a country, which provides various forms of incentives; for example, tax incentives, such as lower taxes for foreign investors, financial incentives, such as grants and confessional loans to multinational corporations, as well as other incentives, such as market needs and monopoly rights.

Because determinants of inward FDI in R\&D are much more specific than attracting greenfield or brownfield investments, there are slightly less research in this issue in the literature. According to the literature, there are several interacting factors making a country attractive to FDI in R\&D. Among the factors related to the host country many of the researchers indicate that the main location drivers are not only the availability of world-class research infrastructure and qualified workforce (EIU 2004), but also the dynamism of the national innovation system, that is, the degree of interaction and collaboration among firms, universities, research centres and industrial associations (Chaminade \& Vang, 2006). The cost of labour may also be a relevant location driver, especially for routine R\&D activities. Other location factors suggested in the existing literature are the presence of multinational enterprises active in R\&D, public incentives to corporate R\&D (i.e. fiscal incentives), clear laws and regulations (i.e. intellectual property rights), the climate and quality of life, the English skills of the local population and the bureaucracy associated with creating and functioning an R\&D enterprise (Guimón, 2009, p. 366). Zanatta and Queiroz (2007) based on China, India and Brazilian cases, identified that national policies are essential to build an economic, institutional and business environment to attract MNCs and their R\&D activities. Conversely, attracting FDI in R\&D requires national investments in innovations or subsidies for the development of research centres, the improvement of a higher education system, the establishment of industrial parks and clusters, and/or the creation of a solid infrastructure (Šimelytè \& Liučvaitienè, 2012, p.69).

Finally, According to UNCTAD (2005, p. 222), in all developing economies that have been successful in improving their innovation capabilities and in attracting R\&D by foreign companies, the government has played a key role. In this paper I focus only on governmental incentives to R\&D-intensive foreign direct investment. 


\section{MATERIAL AND METHODS}

The empirical research conducted for the purpose of this study covers the intensity of FDI among Visegrad countries in the recent years. The study is based on the Eurostat's and OECD's data. Considerations about government incentives are based on information gathered by individual foreign investment promotion agencies. The countries under study are the following: Czech Republic, Hungary, Slovakia and Poland.

A government incentive is understood as any government measure designed to influence an investment decision, or have the effect of increasing the profit, even if these measures do not make direct influence (Ginevičius \& Šimelytè, 2011). Investment incentives could be defined as 'support', 'initiative' as well as 'promotion'. In line with prior studies, incentives have been classified into fiscal, financial measures (such as grants, preferential loans and loan guarantees); non-financial measures (such as promotion, information providing agencies, infrastructure-related assistance, preferential government contracts the provision of certain services, and the establishment of free trade, enterprise and technology zones).

Table 1. Policies framework towards inward R\&D-intensive FDI

\begin{tabular}{|c|c|}
\hline Policy objective & Selected policy instruments \\
\hline Innovation policy & $\begin{array}{l}\text { - } \quad \text { universities, public research centres, science and technology parks, } \\
\text { - } \quad \text { human capital and attraction of foreign talent, } \\
\text { - } \quad \text { fiscal and financial incentives to business } R \& D, \\
\text { - } \quad \text { systemic policies to stimulate linkages and interaction, } \\
\text { - } \quad \text { intellectual property rights regime. }\end{array}$ \\
\hline $\begin{array}{l}\text { Inward investment } \\
\text { promotion }\end{array}$ & $\begin{array}{l}\text { - } \quad \text { international promotion of national technological capabilities, } \\
\text { - } \quad \text { pre-investment services to MNCs, } \\
\text { - } \quad \text { post-investment ("after-care") services to MNCs, } \\
\text { - } \quad \text { policy advocacy. }\end{array}$ \\
\hline
\end{tabular}

Source: (Guimón, 2009, p. 367).

According to Guimón (2009) governments have two types of instruments to encourage the foreign investors: innovation policy and inward investment promotion (Table 1). The role of innovation policy is to improve the investment climate for R\&D by identifying and acting upon the strengths and weaknesses of the national innovation system while the role of inward investment promotion is to improve the image of the country as an R\&D location and to provide targeted services to both potential and existing foreign investors in R\&D.

The aim of this paper consists of identifying and analysing some policy measures of Czech Republic, Hungary, Poland and Slovakia to explore how they affect the attraction and promotion of FDI in R\&D to their countries, as well as their differences and similarities. The analysis base on Guimón's (2009) classification. 


\section{RESULTS AND DISCUSSION}

\section{General Trends in FDI inflow into Visegrad Group Countries}

Since the beginning of the political transformation Czech Republic, Hungary, Poland and Slovakia have become an attractive place of localization of foreign investment. Due to the similarity of development and liberalization processes in these countries, the process of capital inflows in the form of foreign direct investment to the countries of Visegrad Group (V4) is characterized by several common features (Amroziak, 2013; Witkowska, 2011; Zielińska-Głębocka, 2013):

- In the first years of transformation, inflowing foreign capital actively participated in the privatization process, which resulted in the dominance of brownfield investments during this period;

- The following years have brought growing importance of greenfield investments and linkages between foreign companies and parent company in the form of outsourcing and offshoring. The V4 countries at the turn of 20th and 21st century were a place of locating of investment projects, aimed at improving efficiency by minimizing production costs. Inflowing capital served as covering of part of the current account deficits caused by high dynamics of freight import, especially in the supply;

- In all the analysed countries, immediately prior to their accession to the EU, had been noticeable decrease in the activity of foreign investors. The situation changed after EU accession. Between 2004 and 2007 in V4 countries a dynamic inflow of foreign capital was noted;

- The majority of foreign capital in the form of FDI which inflowed into the V4 countries by the end of 2010, came from the EU-15. Investments from these countries were the most important in the Czech Republic and Poland (over $80 \%$ of the total invested foreign capital). The main investors were companies from Germany, the Netherlands, France and Austria;

- Changes in the sectoral structure of cumulative FDI (FDI inward stock) in the V4 countries showed some similarities to the changes occurring during a long time in developed countries. The most significant change was the shift in the structure of cumulative FDI towards services sector. In the services sector a clear shift of FDI to modern services can be observed, which is dominated by financial intermediation, real estate, renting and business activities. There was also the spectacular inflow of foreign capital to the newly created commercial banking sector in the V4 countries. Foreign banks were created mainly in the form of a branch, what allowed the national authorities to supervise them on the basis of the granted license. The transformation of the banking sector was also associated with the processes of mergers and acquisitions.

\section{The Involvement of Foreign Investors in R\&D Activities in the Countries of the Visegrad Group}

In general, the R\&D activities from among all non-production services belong to the least susceptible to the transfer. Despite this, there is a progressive process of internationalization which also includes research and development. R\&D activities require the involvement of significant financial resources. This is related to the necessity of bearing the high costs associated with maintaining the staff, and also purchasing and 
modernization of research equipment. International companies that initiate this activity, have sufficient financial resources and benefit from economies of scale. As part of the internationalization of R\&D multinational corporations situate some R\&D functions of its subsidiaries abroad, including the countries of the Visegrad Group. The measure of their commitment is the expenditure incurred on $R \& D$ activities in these countries and the employment of researchers.

The data presented in Table 2 indicates an increasing involvement of international companies in the field of R\&D in the Visegrad countries. During the first decade of the 21st century there was a dynamic growth in spending on research and development incurred by the subsidiaries of TNCs. Among the countries of the Visegrad Group the largest value of investments in R\&D was made in the Czech Republic (in 2009 it was over USD 1.3 million). Likewise, in this country foreign subsidiaries incurred more than $58 \%$ out of the whole BERD. Poland presents the most dynamic growth in spending on research and development incurred by foreign subsidiaries. The value of such investments has increased almost six-fold in ten years. The value of such investments has increased almost six-fold in ten years. Currently, foreign affiliates in this country finance more than $50 \%$ of research carried out by the enterprise sector, while yet only $12 \%$ of foreign companies participated in this type of projects in 2000. During the analyzed period in Hungary the growth was relatively stable although a high proportion of foreign affiliates invested in financing the research. In turn, foreign subsidiaries in Slovakia are the least active in the market of investment in R\&D. However, this does not mean, that Slovakia's R\&D sector is not an attractive destination for investment.

Table 2. R\&D expenditure of foreign affiliates in Visegrad countries in the years 2000-2009

\begin{tabular}{|c|c|c|c|c|c|c|c|c|c|c|}
\hline \multirow{3}{*}{ Country } & \multicolumn{10}{|c|}{ R\&D expenditure of foreign affiliates } \\
\hline & \multicolumn{2}{|c|}{2000} & \multicolumn{2}{|c|}{2004} & \multicolumn{2}{|c|}{2005} & \multicolumn{2}{|c|}{2008} & \multicolumn{2}{|c|}{2009} \\
\hline & $\begin{array}{c}\text { in } \\
\text { USD }^{a}\end{array}$ & $\begin{array}{c}\text { in } \\
\%^{b}\end{array}$ & $\begin{array}{c}\text { in } \\
\text { USD }\end{array}$ & $\begin{array}{l}\text { in } \\
\%{ }^{b}\end{array}$ & $\begin{array}{c}\text { in } \\
\text { USD }\end{array}$ & $\begin{array}{l}\text { in } \\
\%^{b}\end{array}$ & $\begin{array}{c}\text { in } \\
\text { USD }^{a}\end{array}$ & $\begin{array}{l}\text { in } \\
\%^{b}\end{array}$ & $\begin{array}{c}\text { in } \\
\text { USD }^{\mathrm{a}}\end{array}$ & $\begin{array}{l}\text { in } \\
\%{ }^{b}\end{array}$ \\
\hline Czech Republic & 412.93 & 36.9 & 760.46 & 48. & 978.39 & 51.5 & 1328.64 & 60.4 & 1317.47 & 58.0 \\
\hline Hungary & & & 225.25 & 57. & 305.16 & 59.7 & 420.90 & 57.4 & 446.89 & 52.6 \\
\hline Poland & 113.82 & 12.1 & 133.40 & 16.8 & 287.73 & 30.4 & 387.99 & 40.1 & 614.15 & 50.5 \\
\hline Slovakia & 51.66 & 20.4 & 40.50 & 20. & 52.50 & 23.9 & & & . & \\
\hline
\end{tabular}

${ }^{a}$ million current PPP USD; ${ }^{b} \%$ of R\&D expenditures of enterprises; ( .) - no data

Source: (OECD, 2013).

The growing role of foreign capital in financing research in the countries of the Visegrad Group is also confirmed by Eurostat data (Table 3). In 2012, almost 26\% of research in the Czech Republic, more than $15 \%$ in Hungary, $13 \%$ in Poland and nearly $19 \%$ in Slovakia were financed from abroad. The most dynamic economies in this area are the Czech Republic and Slovakia. 
Table 3. Abroad source of funds of gross domestic expenditure on R\&D in the years 2003-2012 (in \%)

\begin{tabular}{|l|r|r|r|r|r|r|r|r|r|r|}
\hline Countries Year & $\mathbf{2 0 0 3}$ & $\mathbf{2 0 0 4}$ & $\mathbf{2 0 0 5}$ & $\mathbf{2 0 0 6}$ & $\mathbf{2 0 0 7}$ & $\mathbf{2 0 0 8}$ & $\mathbf{2 0 0 9}$ & $\mathbf{2 0 0 1}$ & $\mathbf{2 0 1 1}$ & $\mathbf{2 0 1 2}$ \\
\hline EU-27 & 8.6 & 8.4 & 9.1 & 8.8 & 9.2 & 8.8 & 8.4 & 8.9 & 9.2 &. \\
\hline Czech Republic & 4.6 & 3.7 & 5.4 & 4.8 & 7.3 & 8.9 & 11.3 & 13.9 & 19.7 & 25.9 \\
\hline Hungary & 10.7 & 10.4 & 10.7 & 11.3 & 11.1 & 9.3 & 10.9 & 12.4 & & \\
\hline Poland & 4.6 & 5.2 & 5.7 & 7 & 6.7 & 5.4 & 5.5 & 11.8 & 13.4 & 13.3 \\
\hline Slovakia & 3.3 & 4.3 & 6 & 9.1 & 10.2 & 12.3 & 12.8 & 14.7 & 14.2 & 18.7 \\
\hline
\end{tabular}

Source: (Eurostat, 2013).

One of the important evidences of involvement of foreign investors in the sector of $R \& D$ is a growing number of foreign research centres. Among the most important of them may be mentioned:

- in Czech Republic: Ingersoll-Rand, Honeywell, Rockwell Automation, Roper Industries, Robert Bosch, Siemens Automotive, Volkswagen, Olympus, Matsushita/Panasonic (Czechlnvest),

- in Hungary: Enviroinvest, SAP, Pharmapolis, AMRI,

- in Poland: ABB, Google, Siemens, GlaxoSmithKline, Telcordia, DeLaval, Whirlpool, Motorola, Delhi, Roche, General Electric, McKinsey (PAlilZ, 2010),

- in Slovakia: Johnson Controls Engineering Centre, Siemens Technology Lab, AlcatelLucent R\&D Centre, ON Semiconductor Development Centre, Ness Development Centre, Muehlbauer R\&D Center, Sauer-Danfoss R\&D (Švač, 2010).

Foreign direct investments are often regarded as a source of new technologies in the host country. These technology spillovers have several phases: first when multinational corporations enter the host countries, local enterprises imitate new technology brought by foreign company to improve their production efficiency; this is a direct technology spillover effect. Second, when multinational corporations enter the host country's market, they can intensify competition and force local firms to make full use of current technologies and resources; this is an indirect technology spillover. Third, market competition pressure forces local firms to adopt advanced technologies, which push technological progress (Zhao \& Wang, 2009). Thus, an essential condition of high involvement of transnational corporations in the sector of R\&D may also be a high degree of involvement of foreign investors in the transfer of technology. As we read in the last Global Competitiveness Report (WEF, 2013, p.512), Hungary, Czech Republic and Slovakia obtain more than 5 points (a 7 point scale, where 7 is a greatest extent of FDI being a key source of new technologies) ${ }^{1}$.

This increasing inflow of R\&D investment into the Visegrad Group Countries raises a number of questions which are interesting and relevant for both research and policy making. Where are the multinational R\&D enterprises located? Who are the main foreign investors in the R\&D activity? What factors drive the location choice of multinational R\&D activity? (Siedschlag et al., 2009). To analyse the determinants of the location choice of R\&D, I focus on government investment promotion.

\footnotetext{
1 The question: To what extent does foreign direct investment bring new technology into your country? Hungary obtained 5,3 points, Slovakia: 5,1 points, Czech Republic: 5,1 points, Poland: 4,6 points [ $1=$ not at all; 7 $=$ to a great extent - FDI is a key source of new technology].
} 


\section{Selected Government Incentives for R\&D-Intensive FDI in Visegrad Countries}

The Visegrad countries offer a full package of incentives to attract FDI (Šimelytè \& Liučvaitiene, 2010). The Czech government employs the targeted FDI policy oriented toward specific industry and specific regions. To receive support from the government, investors must meet the requirements which determine the company's activities and on the region where the investment is directed. Czech Republic, offers (1) tax incentives (corporate tax relief for up to 5 years for new companies, partial tax relief for existing companies), (2) job creation grants (financial support for the creation of new jobs), (3) training and retraining grants (financial support for training and retraining new employees), and (4) site support (transfer of public land at a favorable price) (Šimelytea \& Liučvaitienèa, 2010). Czech system of tax incentives offering a special relief for expenditure incurred in research and development, which reaches a size of $200 \%$ of the R\&D projects implementation costs. Czech income tax law allows companies to reduce R\&D spending 100 per cent of their annual tax base, the tax credit for research and development. Tax incentives are available to all businesses regardless of size. Activities eligible for R\&D tax support must meet the OECD Frascati Manual. However, the eligible expenditure on R\&D can be deducted in three consecutive tax years. Deducting the cost of research and development cannot be used for services, royalties and research and development acquired from other persons (Bočková, 2013). Investors in the Czech Republic can benefit from a tax holiday for ten years. This reduction includes investments in centres of technology and centres of strategic services. Foreign investors can benefit from grants for research and development which include capital expenditure (CAPEX) and operating expenses (OPEX). Cash grants of up to $5 \%$ of capital expenditures for R\&D centres are available in the case of strategic investment (Worldwide R\&D, 2013).

Hungary offers the entire package of FDI incentives that consists of the following incentives: (1) cash subsidy granted individually by the Hungarian government, (2) development tax allowance, (3) training subsidy, (4) job creation subsidy, (5) aid cofinancing by the EU (for logistics and manufacturing industry), (6) special incentive packages (for logistics), and (7) other allowance for R\&D sectors. In particular, the Hungarian law contains essentially two types of R\&D tax incentives: deductions from corporate income tax base and tax credits that can be used to reduce tax liability. FDI incentives in R\&D are particularly focused on the automotive sector, which is one of Hungary's core industries. R\&D investment projects must comply with the conditions under which the subsidy is provided. Investments valued at below 10m EUR (or in some cases below 25m EUR) can benefit from EU co-financed subsidies through tenders issued by the Hungarian government. In cases where no EU co-financed subsidy is available, the government offers a special incentive package consisting of the following elements. To receive the subsidy from $10 \%$ to $25 \%$ of the total eligible cost, the foreign investor must invest at least $10 \mathrm{~m}$ EUR. The investor may receive the exemption of $80 \%$ of the corporate tax payable for 10 years if the investment in R\&D exceeds $100 \mathrm{~m}$ EUR. The training subsidy between $25 \%$ and $90 \%$ of the eligible training costs is provided if more than 50 new jobs are created. The job creation subsidy is provided according to the individual decision if jobs are created in underdeveloped or less developed regions. Additionally, if investment is located at a university or public research institute, other R\&D incentives

cover corporate tax deductions, $300 \%$ of R\&D expenses (maximum $0.2 \mathrm{~m}$ EUR) (Šimelytė 
\& Liučvaitienè, 2010). In Hungary, investors can benefit from double deduction of R\&D costs. The direct costs of R\&D or the depreciation of capitalized R\&D costs incurred in a given tax year are deductible twice for CIT purposes: once as an expense, second as a CIT base deduction item (Worldwide R\&D, 2013). Investors, for a period of 3 years, can deduct $10 \%$ of $R \& D$ direct costs and wage costs of software developers. Tax free employment of PhD, MSc or MBA students up to the official minimum wage has been introduced. Deduction from the income of $200 \%$ of eligible expenses in connection with carrying out R\&D work is a special relief of R\&D investing in Hungary (Deloitte, 2013). Consequently, Hungary implemented a strictly regulatory FDI policy that is highly oriented towards R\&D sectors.

Slovakia is also implementing the targeted FDI policy oriented towards R\&D investments. Highly prospective opportunities for doing R\&D business in Slovakia are associated with: automotive industry and supplier sector, electrotechnics and electronics, energetics and renewable energy sources, new materials and lightweight materials, biotechnology sector, ICT and software development (Invest in Slovakia, 2012). R\&D businesses can apply for regional investment aid, aid work, helping to build a technology centres or on its extension. As in other previously analyzed countries, investors are given grants if they meet specific conditions. Slovakia offers (1) corporate income tax relief, (2) contributions for the creation of new jobs, (3) transfer of title to immovable property of the state or municipality at a price lower than standard market price, (4) financial grants, and (5) education allowances as a form of aid. The government provides from $20 \%$ to $50 \%$ finance of the total investment venture, which depends on the project. To avoid double taxation, dividend, gift, inheritance, and real estate transfer taxes are abolished. The state support in R\&D is applied for both foreign and local investors. However, support intensity is differentiated by the size of a company. For example, in the area of applied research, $75 \%$ of the eligible costs are funded for SMEs and $65 \%$ for large enterprises. Furthermore, to receive aid from Slovakia's government, $41.5 \mathrm{~m}$ to $43.5 \mathrm{~m}$ EUR must be invested in applied research projects (Šimelyte \& Liučvaitienè, 2012, p. 84). Slovakia has, since 2009, R\&D tax incentives. According to Act No. 185/2009 companies may apply for grants from the state budget to support basic research, applied research or experimental development, the temporary placement of highly qualified R\&D personnel. Relief for tax incentives are provided for three consecutive tax periods (Bočková, 2013, p. 875).

To attract the foreign capital, Poland founded 14 Special Economic Zones (SEZ) providing favourable conditions for economic activity. In Poland, grants are provided to foreign investors under the regional investment and employment aid scheme (income tax exemption in a SEZ), which may not exceed $50 \%$ of the total amount of grant. Poland focuses on six priority sectors (automotive, electronics, aviation, modern services, research and development, and biotechnology). There are also subsidies from EU funds and the state budget covering up to $100 \%$ of expenditure on R\&D (Deloitte, 2013). In Poland, the main two measures aimed at supporting R\&D activities and innovation activities include provisions on the status of R\&D centre position, which provides for special tax exemptions and depreciation, namely monthly expenditure on innovation fund and aid for the purchase of new technology. R\&D centres can set up an innovation fund. The Fund is powered by monthly deductions of $20 \%$ of revenue. In addition, 
companies can deduct from taxable income up to $50 \%$ of the expenditure incurred on the purchase of new technology in the form of intangible assets, for example, the rights arising out of the ownership, licensing, rights under patent or utility model, the knowhow (Deloitte, 2013). To be eligible for state aid in the R\&D sector, 35 new jobs shall be created and $775 \mathrm{k}$ EUR invested. In other sectors, such as automotive, electronics, aviation, and modern sectors, investors seeking to cover the cost associated with the creation of jobs must create 250 new jobs and invest 10.3m EUR (Šimelyte \& Liučvaitienè, 2012, p. 82).

Table 4. Summary of available incentives to R\&D investment in Visegrad countries

\begin{tabular}{|c|c|c|c|c|c|c|c|c|c|}
\hline Country & 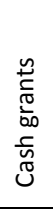 & 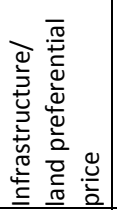 & 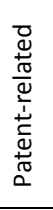 & 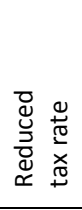 & 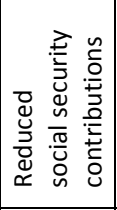 & 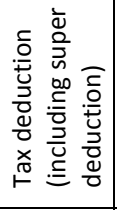 & 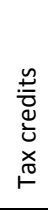 & 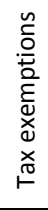 & 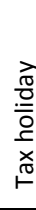 \\
\hline Czech Republic & $\mathrm{x}$ & $\mathrm{x}$ & & & & $\mathrm{x}$ & & & $\mathrm{x}$ \\
\hline Hungary & $x$ & & $x$ & $x$ & $\mathrm{x}$ & $x$ & $x$ & & \\
\hline Poland & $x$ & & & & & $x$ & & $x$ & \\
\hline Slovakia & $x$ & $x$ & $x$ & & & & $x$ & & $\mathrm{x}$ \\
\hline
\end{tabular}

Source: (Worldwide R\&D, 2013, p. 2-3).

Table 4 presents a summary of available incentives to potential R\&D investors in Visegrad countries. Due to limited capacity, not all of these incentives have been discussed. An analyisi of key incentives indicates that the most government incentives exist in Hungary, the least - in Poland. In the face of the objectives of the Europe 2020 Strategy ${ }^{2}$, it seems that created incentives in the Czech Republic, Hungary and Slovakia will foster the development of innovative economies. Thus, Poland seems to be behind on the map of Central and Eastern Europe in trying to encourage investment in R\&D only by subsidies.

The second instrument of influencing by government to invest in R\&D sector is the inward investment promotion. The purpose of investment promotion is to reduce transaction costs facing foreign investors by providing information (on business opportunities, prevailing laws and regulations as well as factor cost in a host country) and helping foreign investors deal with bureaucratic procedures (Harding \& Javorcik, 2011 , p. 1445). Investment promotion agencies to a large extent are responsible for encouraging and promoting its countries in the international arena of capital flow. In the Czech Republic this task is performed by Czechlnvest, in Hungary - HITA, in Poland PAlilZ, in Slovakia - SARIO. Literature addresses that a main role of the IPA is to gather and distribute the information that prospective investors need to evaluate the attractiveness of a country as an investment site. In other words, IPA could play a role in influencing FDI decisions by compensating for market failure due to information or perception gaps about investment conditions or investment country's climate (Lim, 2008 , p. 41). Investment promotion practitioners believe that the most effective way of attracting FDI is to focus on a few priority sectors (target sectors) rather than attempting

\footnotetext{
${ }^{2}$ The Europe 2020 strategy sets a $3 \%$ objective for R\&D intensity (R\&D expenditure as a percentage of GDP).
} 
to attract all types of foreign investors. The idea behind targeting is that a more focused message tailored and delivered to a narrow audience will be more effective than general investment promotion activities (Harding \& Javorcik, 2011, p. 1450).

It should be noted that all the above-mentioned agencies, conduct a campaign to promote R\&D sector as the place of location of foreign investment. Their activities bring the tangible results in the form of new investment projects. In this issue, the activities of Polish agency (PAlilz - Polish Information and Foreign Investment Agency) can be positively assessed. The Agency has consistently pursued its objectives by attracting investors which are characterized by high productivity, increasing value added (by the introduction of modern technology, the production of innovative products), and creating jobs requiring high qualifications. These investors contribute to raising the competitiveness of the whole country. For instance, in 2013 PAlilZ completed 7 (with 53) investment projects in the R\&D sector in Poland, with a value of $89.2 \mathrm{~m}$ EUR, giving employment to 875 people (PAlilZ, 2013). However, the process of finding an investor (especially in the research and development) is very long, and the investment decision can be taken even after two years from the start of the promotional activities (Kuźmińska-Heberla, 2012, p. 164).

\section{CONCLUSIONS}

The conducted analysis of statistical data confirms the growth of foreign investment in the research and development in the countries of the Visegrad Group. During the last 10 years a significant increase of these investments was noted in the Czech Republic and Poland. However, it seems that these investments are still too low to significantly improve the overall innovation level of the V4 countries. This may be associated with the fact that many of TNCs locate their R\&D activities into developed (USA, UK) or developing countries in Asia (China, India). Are, therefore, the efforts of the governments of the Visegrad countries enough to encourage foreign investors to invest in their research and development sector?

The analysed activities and investment incentives employed by governments do not confirm, that the government activities are an important factor in this type of investment. The V4 countries lead a relatively liberal policy towards foreign investors, offering a number of fiscal and financial incentives admittedly conditioned with certain requirements. Especially, Hungarian and Slovak investment promotion agencies lead aggressive campaigns in the international arena. However, as we see in the latest report, the 2013 Survey on R\&D Investment Business Trends, prepared by the European Commission, only Poland (among all the countries of the Visegrad Group) was among the most attractive countries for $R \& D$ investments. This is surprising taken that compared to other V4 countries, Poland provides the poorest system of incentives. Therefore, it is clear that investment incentives are effective only when the country meets numerous other conditions required by the international company.

The study presented in this article is only the starting point for a further discussion. It seems that the issue of FDI inflow to R\&D sector in the V4 countries is crucial from the point of view of a knowledge-based economy. Therefore, further studies on this issue should seek to establish which factors have the strongest impact on the inflow of FDI into R\&D sector in the V4 countries. 


\section{REFERENCES}

Ambroziak, Ł., 2013, Wpływ bezpośrednich inwestycji zagranicznych na handel wewnq̨trzgałęziowy państw Grupy Wyszehradzkiej, IBRKK, Warszawa.

Bočková, N., 2013, 'Visegrad Four Countries: Evaluation in R\&D Sectors of Performance', Acta Universitatis Agriculture et Silviculturae Mendelianae Brunensis, vol. LXI, no. 4, pp. 873-880.

Chaminade, C. \& Vang, J., 2006, Globalization of Knowledge Production and Regional Innovation Policy: Supporting Specialized Hubs in Developing Countries, CIRCLE Electronic Working Paper 2006/15.

CZECHINVEST, Available from: <http://www.czechinvest.org/> (accessed December 2013).

Deloitte, 2013, Przeglqad zachęt na działalność B+R na świecie w 2013 r., Deloitte Global Services Limited.

Dunning, J., 1993, Multinational Enterprises and the Global Economy, Wokingham, England and Reading Mass: Addison Wesley.

Dunning, J. \& Lundan, S., 2008, Multinational Enterprises and the Global Economy, Second Edition, Edward Elgar Publishing.

Dunning, J. \& Narula R., 2000, 'Industrial Development, Globalization and Multinational Enterprises: New Realities for Developing Countries', Oxford Development Studies, vol. 28, no. 2, pp. 141-167.

Economist Intelligence Unit (EIU), 2004, Scattering the seeds of invention. The globalization of research and development, The Economist Intelligence Unit, London.

Eurostat, 2013, Eurostat Database, Available from <http://epp.eurostat.ec.europa.eu> (accessed December 2013).

Ginevičius R. \& Šimelytė A., 2011, 'Government incentives directed towards foreign direct investment: a case of Central and Eastern Europe', Journal of Business Economics and Management, vol. 12, iss. 3, pp. 435-450.

Guimón, J., 2009, 'Government Strategies to Attract R\&D-intensive FDI', Journal of Technology Transfer, vol. 34, iss. 4, pp. 364-379.

Havranek, T. \& Iršova, Z., 2010, 'On the Intensity of International Subsidy Competition for FDI', Theoretical and Applied Economics, vol. 17, iss. 2, pp. 25-54.

Harding, T. \& Javorcik, B. S., 2011, 'Roll out the Red Carpet and They Will Come: Investment Promotion and FDI Inflows', The Economic Journal, vol. 121, iss. 557, pp. 1445-1476

Kuźmińska-Heberla, A., 2012, 'Rezultaty działań Polskiej Agencji Informacji i Inwestycji Zagranicznych S.A. w zakresie przyciągania inwestorów zagranicznych w latach 2003-2010 próba oceny', Studia Ekonomiczne, Uniwersytet Ekonomiczny w Katowicach, nr 116.

Lim, S., 2008, 'How investment promotion affects attracting foreign direct investment: Analytical argument and empirical analyses', International Business Review, vol. 17, issue 1, pp. 39-53.

Miyagiwa, K. \& Ohno, Y., 2008, 'Multinationals, Tax Holidays and Technology Transfer', Japanese Economic Review, vol. 60, no. 1, pp. 82-96.

Morisset, J. \& Pirnia, N., 2000, The Impact of Tax Policy and Incentives on FDI, Rutledge.

OECD, 2013, OECD database, Available from: <http://stats.oecd.org/> (accessed December 2013).

PAlilZ, 2010, Sektor badawczo-rozwojowy w Polsce, Polska Agencja Informacji i Inwestycji Zagranicznych, Warszawa.

PAlilZ, 2013, Available from: <http://www.paiz.gov.pl/>(accessed December 2013). 
Peters, A. \& Fisher, P., 2004, 'The failures of Economic Development Incentives', Journal of American Planning Association, vol. 70 , no. 1, pp. 27-37.

Resmini, L., 2000, 'The determinants of foreign direct investment in the CEECs. New evidence from sectoral patterns', Economics of Transition, vol. 8, no. 3, pp. 665-689.

Rosenboim, M., Luski, I., Shavit, T., 2008, Behavioural Approaches to Optimal FDI Incentives, Managerial and Decision Economics, No. 29, p.601-607.

R\&D in Hungary. With Business in Mind, 2010, ITD Hungary.

Saggi, K., 1999, 'Foreign Direct Investment, Licensing and Incentives for Innovation', Review of International Economics, vol. 7, no. 4, pp. 699-714.

SARIO, 2012, Invest in Slovakia, Slovak Investment and Trade Development Agency, Bratislava.

SARIO, Available from: <http://www.sario.sk/> (accessed December 2013).

Siedschlag, I., Smith, D., Turcu, C., Zhang X., 2009, 'What Determines the Attractiveness of the European Union to the Location of R\&D Multinational Firms?', ESRI Working Papers, no. 306

Šimelytė, A. \& Liučvaitienè A., 2012, 'Foreign Direct Investment Policy-Friendly Business Environment in R\&D Sectors: Baltic States versus Visegrad Countries', Journal of East-West Business, vol.18, no. 1, pp. 66-93.

Švač, V., 2010, R\&D in Slovakia, Slovak Investment and Trade Development Agency, SARIO, Bratislava.

The 2013 Survey on $R \& D$ Investment Business Trends, 2013, European Commission, Luxembourg

UNCTAD, 2005, World Investment Report 2005: Transnational Corporations and the Internationalization of $R \& D$, Geneva, United Nations.

WEF, 2013, The Global Competitiveness Report 2013-2014, Klaus Schwab, World Economic Forum.

Witkowska J., 2011, 'Rola kapitału zagranicznego w modernizacji gospodarki nowych krajów członkowskich Unii Europejskiej. Aspekty porównawcze', PTE Zeszyty Naukowe, no. 9, Kraków.

Worldwide R\&D incentives reference guide 2013-2014, 2013, EY Building a better world, EYGM, Available from: < http://www.ey.com> (accessed December 2013).

Zanatta, M. \& Queiroz, S., 2007, 'The Role of National Policies on the Attraction and Promotion of MNEs' R\&D Activities in Developing Countries', International Review of Applied Economics, vol. 21, no. 3, pp. 419-435.

Zielińska-Głębocka A., 2013, 'Sytuacja gospodarcza państw Grupy Wyszehradzkiej w procesie transformacji i integracji z Unią Europejską'. In A. Zielińska-Głębocka, K. Gawlikowska-Heuckel (Eds), Konkurencyjność międzynarodowa i regionalna państw Grupy Wyszehradzkiej: Polski, Węgier, Czech i Słowacji, Wyd. UG, Gdańsk.

Zhao J. \& Wang K., 2009, 'Analysis of the Technology Spillovers of Multinational Corporations', Transnational Corporations Review, vol. 1, no. 2, pp. 28-38. 


\section{Author}

\section{Magdalena Owczarczuk}

Assistant lecturer at the Department of Political Economics of the Faculty of Economics and Management of the University of Białystok (Poland).

\section{Correspondence to:}

Mgr Magdalena Owczarczuk

University of Bialystok

Faculty of Economics and Management

Department of Political Economics

ul. Warszawska 63, 15-062 Białystok, Poland

m.owczarczuk@uwb.edu.pl 